Article

\title{
The Energy Upgrading of Existing Buildings: Window and Shading Device Typologies for Energy Efficiency Refurbishment
}

\section{Cristina Carletti ${ }^{1}$, Fabio Sciurpi ${ }^{1, *}$ and Leone Pierangioli ${ }^{2}$}

1 Department of Industrial Engineering, University of Florence, via San Niccolò 93, Firenze 50125, Italy; E-Mail: cristina.carletti@unifi.it

2 Department of Architecture, University of Florence, via San Niccolò 93, Firenze 50125, Italy; E-Mail: leone.pierangioli@unifi.it

* Author to whom correspondence should be addressed; E-Mail: fabio.sciurpi@unifi.it; Tel.: +39-055-275-5346; Fax: +39-055-275-5355.

Received: 11 June 2014; in revised form: 10 July 2014 / Accepted: 31 July 2014 /

Published: 18 August 2014

\begin{abstract}
Residential buildings built after the Second World War have high energy consumption and inadequate thermal comfort, especially in summer conditions, largely attributable to the high transmittance of windows and lack of effective shading devices. Performance improvement of these components is essential for energy upgrading of existing buildings. This paper shows the results of the research, which aims to evaluate effects on energy consumption and environmental comfort of combined solutions of windows and shading devices applied to a case study representing a typical post World War II Italian building. In this paper, the main typologies of solar control systems are described and evaluated on the basis of a case study in different climatic locations (Berlin, Milan, Florence and Athens). Thermal behavior has been assessed through the EnergyPlus dynamic calculation code, by using appropriate performance indicators for energy and thermal sensation. Starting from performance evaluation of the existing building, different strategies have been assessed: replacement of existing windows with high-energy performance ones and introduction of shading devices and solar control glasses. Finally, a global comparative analysis has been carried out based on energy, acoustic and lighting performances, technical feasibility and management problems. Results of the different solar shading devices assessment are reported in the form of a data sheet.
\end{abstract}

Keywords: energy retrofit; transparent building envelope; solar shading devices 


\section{Introduction}

Since the building sector is responsible for almost $40 \%$ of European primary energy demand, the European Directives 2002/91/EC and 2010/31/EU on energy performances of buildings promote passive design strategies oriented to improve energy performance of the building envelope, in order to reduce heating and cooling loads.

Among passive design strategies, those concerning windows and solar shading devices play an important role, since these elements have a relevant impact on energy and thermal behavior of buildings.

The connection between internal environment and outside through glazed surfaces calls for three specific requirements:

- Control of heat flow through components with a low thermal inertia;

- Regulation of solar radiation access;

- Provision of adequate visual connection to outdoors and satisfactory level of natural light, avoiding visual comfort detriments (such as glare, etc.).

Since conventional windows are the weakest part of the building envelope, as their thermal resistance is much lower than adjacent walls, the first requirement is strictly related to energy efficiency and had pushed forward the development of components_-glass panes, frames and window spacers - with low transmittance values. Reduction of heat transfer through windows is possible thanks to the development of several solutions, such as the application of gas layer with a thermal conductivity lower than air, the introduction of low emissivity coating film, the addition of interspaces fractionation with multi glazing systems, metallic frames with multiple air cavities and thermal breaks and the adoption of spacers made of low thermal conductivity materials [1,2]. Furthermore, these improved performances are producing positive outcomes in term of thermal and acoustic comfort.

The second requirement concerns the choice of proper solar shading devices which are asked to fulfil two conflicting aims: to maximize winter solar gain, which is desirable as it reduces heating energy demand and, equally, to prevent excessive summer solar gain as it is one of the factors responsible for overheating conditions and cooling energy demand.

The third requirement is prominently focused on a visual comfort level provided by the combined effect of window and solar shading device installation.

Moreover, windows, transparent facades and shading devices have to guarantee specific performances regarding safety, mechanical resistance, aesthetics and protection against noise, wind and rain.

Since the amount of heat transferred both in winter and summer through glazed surfaces represents a relevant portion of building energy balance for space heating and cooling, building energy retrofit by means of windows replacement and shading devices installation has an huge potential for energy saving and, if promoted by tax incentives is favorably cost-effective.

The variety and technical evolution of available typologies of window and shading devices, combined with the support of detailed computational software and LCA analysis tools, allow the designer to make a careful choice of glazing properties and shading device characteristics in order to achieve a reduction in energy consumption and provide comfort for the occupants $[3,4]$.

Many recent studies investigate how combined solutions of different types of glazing and solar shading devices affect energy demand, visual and thermal comfort of buildings. These researches show 
that a relevant reduction of buildings energy consumption and increase of thermal comfort level can be achieved by means of optimized design of glazed surfaces and shading devices [5].

Most of the studies concern office buildings which, due to large glazed surfaces, require a careful analysis of the effectiveness of solar shading devices [6]. However, some studies investigate the optimal combination of available types of windows and shading devices for homes and residential buildings.

The current production of residential windows can be classified according to: type of opening (casement, sash, horizontal sliding, awning, hopper, tilt and slide, tilt and turn or fixed windows), type of frame materials (wood, wood incorporating polyurethane (PUR), wood with insulation filled and aluminum cladding, polyvinylchloride (PVC), PVC with insulation filled and aluminum cladding, aluminum and aluminum with PUR insulation), type of glass (double or triple glazing, low-e, heat absorbing and solar control) and type of spacers between the panes (aluminum, stainless steel, PVC and steel, thermoplastic and composite materials) [1]. Moreover, windows can be classified into classes with regard to air permeability [7], water tightness [8] and wind resistance [9].

The thermal performance of the window is related to the total solar energy transmittance $(\mathrm{g})$ and with the thermal transmittance value $\left(U_{w}\right)$, which is determined by the thermal transmittance of glass $\left(\mathrm{U}_{\mathrm{g}}\right)$, of the frame $\left(\mathrm{U}_{\mathrm{w}}\right)$ and glass-edge linear thermal transmittance $\left(\psi_{\mathrm{g}}\right)[10]$.

The effectiveness of sun protection of a glazed surface and its visual comfort performance depends on light transmittance $\left(\tau_{\mathrm{v}}\right)$ and the color rendering index $\left(\mathrm{R}_{\mathrm{a}}\right)$ of the glazing. Solar control glasses have on a selective coating, which contributes to reduce $g$ value with a low as possible detriment of $\tau_{\mathrm{v}}$ and $\mathrm{R}_{\mathrm{a}}$ levels.

Tsikaloudaki et al. [11], by means of parametric analysis performed through Energy Plus simulation software, studied the effect of the window optical and thermal characteristics on the cooling energy demand of a sample home room located in Athens and in other cities in the Mediterranean area. It was found that windows with low $U_{w}$ values, if installed in South European warm climates without proper solar shading, may increase the cooling load since their low thermal transmittance prohibits the dissipation of the internal heat. In these climatic contexts, the presence of shading devices combined with moderate $g$ values glazing results in minimization of cooling loads of residential buildings.

Studies by Yao $[12,13]$ on energy efficiency of a typical multi-story apartment building, located in hot summer and cold winter zone of China, show that adding moveable internal shadings on east and west facing windows contributes to improve the whole building energy performance and to reduce, in term of total energy demand, the gap between differently oriented and shaped apartments. By a multi-objective life cycle analysis, it was also found that this strategy contributes to enhance energy, economic and environmental performance of the studied building.

Shading devices can be classified regarding their position to the window-external, internal and intermediate — and their operation — fixed or movable.

Even if residential buildings are mostly equipped with internal devices, such as drapes, roller shades or venetian blinds, external shading devices are much more effective in reducing cooling loads and overheating risk, as they intercept and reduce incident solar radiation before it pass through the glass panes, preventing therefore greenhouse effect taking place within the house spaces.

In general, an external shading device (solid or louvered overhangs, side fins, vertical louvers with horizontal or vertical blades, egg-crate louvers, awnings, roller shades, etc.) can be applied just to the window or to a portion or entire facade. In this case, the application of shades also adds aesthetic value 
to the renewal of the facade, allowing a new perception of the existing building. External louvers with vertical blades which can rotate by about $180^{\circ}$ are used primarily for office and industrial application. Louvers for external shading devices come with various section profiles (ellipsoidal which is the most common, curved, gull wing, triangular, diamond, and rectangular) and their orientation can be fixed, accordingly to summer sun position, or automated by light or solar sensors which allow a continuous variation according to the daily sun path.

The selection of external shielding components must take into account outdoor weather conditions and the device wind resistance. Furthermore, the placement of the shading outside also allows interacting with the outer sound waves - for instance traffic. Thus, if properly designed, external shading devices can help to significantly reduce the sound pressure incident on the facade [14]. However external shading devices are usually more expensive and need more maintenance, since they are permanently exposed to atmospheric agents.

Intermediate solar shading combines in one building component the glazing and the shading device which, in this case, is a venetian blind system, with smaller slats, placed in the cavity of the double glazing. This hybrid system provides a satisfactory level of solar radiation control, representing an effective alternative to external devices.

Kim et al. [15] compare, by means of energy simulation, three different types of external shading devices (a solid overhang, a horizontal louvered light shelf and an experimental tilted louvered overhang) with an internal venetian blind in terms of energy savings for heating and cooling. The investigation shows that, regardless of slat angles, the internal venetian blind is much less effective in reducing cooling loads than external devices and that, considering both summer and winter performance, the experimental tilted louvered overhang provides the most effective energy reduction.

Other studies on the effect of blind position on heating and cooling energy demand found that external devices are effective in reducing cooling energy demand while the presence of indoor side blinds can reduce heating energy requirement only in specific climatic contexts $[6,16,17]$.

Table 1 reports a summary of the benefits of solar shading devices with respect to their position considering energy performance and comfort [3].

Table 1. Benefits of solar shading with respect to its position.

\begin{tabular}{cccccc}
\hline Position & $\begin{array}{c}\text { Summer Thermal } \\
\text { Gains }\end{array}$ & $\begin{array}{c}\text { Winter Thermal } \\
\text { Gains }\end{array}$ & $\begin{array}{c}\text { Summer Thermal } \\
\text { Comfort }\end{array}$ & Visual Comfort & $\begin{array}{c}\text { Acoustic } \\
\text { Comfort }\end{array}$ \\
\hline External & ++ & - & ++ & + & + \\
Intermediate & + & + & + & + & - \\
Internal & - & ++ & - & + & - \\
\hline
\end{tabular}

Legend: $++=$ Very favorable effect; $+=$ Positive effect; $-=$ No effect or potentially negative effect

Fixed shadings (overhangs, side fins, canopies, balconies, frames, egg-crate louver, etc.) do not allow variation of solar radiation and light control in response to climatic variation. Generally, the geometric characteristics of this kind of shades are fixed according to the sun incidence angle of the hottest period of the year. These systems may become a very important formal element in the project.

Regarding external fixed shading devices, Lai and Wang [18] and Cheung et al. [19] found that, for residential building located at tropical latitude, external fixed shading devices—such as $1.5 \mathrm{~m}$ depth 
overhang or balcony and side-fins - are effective in order to reduce cooling energy demand. In addition, for higher latitudes, like Cyprus, $1.5 \mathrm{~m}$ depth overhang may be optimal, considering annual energy performance for heating and cooling [20]. Moreover, in this kind of climate, the reduction of cooling energy demand through the installation of overhang is more effective if the opaque envelope has been retrofitted by means of an insulation layer.

In the study by Palmero-Marrero and Oliveira [21], geometric variables of external louvers-such as blades spacing and inclination-were optimized to provide shading in summer and solar gain in winter, for South orientation, in Mexico City, Cairo, Lisbon, Madrid and London latitudes. Then the effect on cooling and heating energy demand and on operative and indoor air temperature of horizontal and vertical louvers applied, respectively, to south and west-east facade of a sample single zone building, was investigated by means of energy simulation. The results show that, if louvers design is optimized, a significant space cooling energy reduction can be achieved in all the cities, especially in Cairo, Lisbon and Madrid where solar radiation is higher in summer. In the northernmost location-London - the louver shading devices used all year round could increase the total annual energy demand, due to the reduction of solar gains in the heating season, which is dominant in those climates. In these cases, louvers should be packed by means of automatic devices. Moreover blades tilting should be optimized taking into account visual comfort since high blades tilting angles, which provide good summer energy performance, could lead to poor visibility.

Mobile shading devices (venetian blinds, roller blinds, curtains, etc.) permit, manually or by automated systems, to adapt to the sun path daily and yearly, due to a punctual control of the shading elements based on solar radiation, indoor temperature or illuminance level. Generally, mobile blinds achieve lower yearly energy demand for heating and cooling than fixed systems because, as they decrease the cooling load, they do not reduce the possible benefit for heating with solar gain in winter.

In general much research, especially for office buildings, investigates the benefit of the total annual energy demand for heating, cooling and lighting of automated or manual control of shading devices [22-24]. Coupling Energy Plus simulations with a stochastic model of shades control, Yao [25] found that manually adjusted external roller shades, applied to an office building located in the Chinese city of Ningbo, perform better than Low-E glass with respect of total energy demand. Furthermore, Yao [26], by means of field study and simulation found that, also in residential buildings, manual control of movable roller blinds or venetian blinds provide relevant performance in terms of energy saving indoor thermal and visual comfort.

Nikoofard et al. [17] studied residential buildings energy retrofit by means of shading devices installation. The effect of venetian blinds characteristics on heating and cooling energy demand was investigated through a preparatory parametric analysis performed for a single house located in Toronto, Canada. It was found that gradually tilting the slats results in heating energy demand increasing that is larger, in magnitude, than the corresponding reduction in cooling energy demand. As for the blind position, outdoor blinds are more effective than indoor ones in reducing cooling energy requirement but they can result in a heating energy demand increase. Regarding slat orientation, it was found that horizontal slats decrease cooling energy requirement and increase heating energy requirement more than vertical ones. The research concludes that, regarding the Canadian climate and housing stock, the optimal venetian blind configuration, in respect of annual energy demand and greenhouse gas emissions, is light aluminum placed on the indoor side of windows coupled with 
automatic control based on zone temperature. Other outdoor placed venetian blinds are effective in reducing cooling energy consumption, but, considering cold climate, they result in an increase in overall energy consumption when both heating and cooling seasons are considered.

Table 2. Main types of solar control systems applicable to residential buildings.

\begin{tabular}{|c|c|c|c|}
\hline $\begin{array}{l}\text { Fixed horizontal } \\
\text { Sunscreen }\end{array}$ & $\begin{array}{l}\text { Fixed Overhang } \\
\text { (example C2) }\end{array}$ & Sunscreen Fixed Blade & $\begin{array}{l}\text { Sunscreen Fixed Blade } \\
\quad(\text { example C4) }\end{array}$ \\
\hline $\begin{array}{l}\text { Fixed horizontal blades } \\
\text { or grilles anchored to a } \\
\text { structure perpendicular } \\
\text { to the facade. } \\
\text { Structure materials: } \\
\text { aluminum, galvanized } \\
\text { steel, etc. }\end{array}$ & $\begin{array}{l}\text { Fixed horizontal/vertical } \\
\text { overhang-wall anchored } \\
\text { or autonomous - opaque. } \\
\text { Materials: sheet metal, } \\
\text { treated wood, plastic } \\
\text { materials, photovoltaic } \\
\text { panels, concrete, etc. }\end{array}$ & $\begin{array}{l}\text { Pre-oriented horizontal } \\
\text { blades fixed to the facade. } \\
\text { Blades can also be applied } \\
\text { to shield balconies. } \\
\text { Blade materials: extruded } \\
\text { aluminum, wood, PVC, } \\
\text { brick, etc. }\end{array}$ & $\begin{array}{l}\text { Pre-oriented vertical } \\
\text { blades fixed to the } \\
\text { facade. Vertical blades } \\
\text { are more frequent in } \\
\text { east/west orientation and } \\
\text { commercial buildings. } \\
\text { Blade materials: extruded } \\
\text { aluminum, wood, PVC, } \\
\text { brick, etc. }\end{array}$ \\
\hline $\begin{array}{l}\text { Venetian Blinds } \\
\text { (example } \mathrm{C} 1 \text { ) }\end{array}$ & $\begin{array}{l}\text { Venetian Blinds } \\
\text { (example C3) }\end{array}$ & Persian Shutter & $\begin{array}{l}\text { Solar control glass } \\
\quad(\text { example C5) }\end{array}$ \\
\hline $\begin{array}{l}\text { Blind for outdoor use } \\
\text { with adjustable and } \\
\text { packable slats. Its } \\
\text { packaging allows } \\
\text { a very compact folded } \\
\text { element once rolled in. } \\
\text { Blind section: } \\
\text { Z-shape, arched. } \\
\text { Blind materials: } \\
\text { aluminum alloy, etc. }\end{array}$ & $\begin{array}{l}\text { Blind for outdoor use } \\
\text { with adjustable and } \\
\text { packable slats. This } \\
\text { typology can also be } \\
\text { applied to screen } \\
\text { balconies for the whole } \\
\text { facade width (for new } \\
\text { buildings or for energy } \\
\text { and architectural } \\
\text { refurbishment of } \\
\text { existing buildings). } \\
\text { Blind section: } \\
\text { Z-shape, arched. } \\
\text { Blind materials: } \\
\text { aluminum alloy, etc. }\end{array}$ & $\begin{array}{l}\text { Hinged or sliding shutters, } \\
\text { made with fixed or } \\
\text { movable blinds, allowing } \\
\text { good modulation of solar } \\
\text { radiation and light. } \\
\text { Applicable in residential } \\
\text { buildings and suitable } \\
\text { for interventions in } \\
\text { historical buildings. } \\
\text { Blind materials: wood, } \\
\text { aluminum, PVC, etc. }\end{array}$ & $\begin{array}{l}\text { Glass provided with a } \\
\text { protective coating on the } \\
\text { surface, to control solar } \\
\text { radiation transmission and } \\
\text { to reduce glass total solar } \\
\text { energy transmittance. }\end{array}$ \\
\hline
\end{tabular}

Considering that solar radiation entering residential buildings commonly represents the largest heat gain of this kind of buildings, its control by means of coupled glazing and shading device is not only 
necessary in buildings with large glazed surfaces but it is crucial for existing residential buildings retrofit and design of new energy efficient residential buildings. Moreover, in new or energy refurbished buildings the enhanced thermal insulation and air tightness of the envelope enlarges the sensitivity of building energy behavior to solar gains. In these cases, the lack of effective control of solar gains could neutralize the benefit of the thermally improved envelope [16,17].

For these reasons this study investigates the effect, in term of solar gain reduction and thermal sensation, of the energy retrofit of an existing residential building sample room by means of a new window with moderate $U_{w}$ and $g$ values, and external shading devices installation. Solar shading devices have been chosen among those applicable to residential buildings and, moreover, compared with the installation of a solar control glass.

Table 2 shows the main types of solar control systems suitable for residential buildings. Data are referred to current production, so variations are possible in terms of material related to technological development in the sector.

\section{Integrated Solutions Applied to a Case Study}

The performances of different strategies for upgrading the energy efficiency of existing buildings are evaluated on the basis of a case study, representing a room of a typical post World War II Italian residential architecture. Different strategies concerning windows and solar shadings have been applied to this model, and assessed by means of a dynamic calculation code-EnergyPlus, through the Design Builder interface. Glazing and solar shading devices have been modelled in EnergyPlus by means of detailed - layer-by-layer - modeling approach using glass panes full spectral properties [27].

Four representative climatic datasets corresponding to various European locations-Berlin, Milan, Florence and Athens-were considered (Table 3). The hourly values of dry bulb temperature of the outside air and solar radiation to perform energy simulations are from the Institute "Gianni De Giorgio" archive (IGDG), for Milan and Florence, and from the International Weather for Energy Calculations archive (IWEC), for Berlin and Athens. Figure 1 and Figure 2 show monthly mean values of dry bulb temperature and monthly solar irradiation amounts for each location.

Table 3. Main climatic aspects of the examined locations.

\begin{tabular}{cccc}
\hline Location & Latitude & Heating period & Cooling period \\
\hline Berlin & $52.57^{\circ}$ & October 1-April 30 & June 1-August 31 \\
Milan & $45.43^{\circ}$ & October 15-April 15 & May 15-September 30 \\
Florence & $43.80^{\circ}$ & November 1-April 15 & May 1-October 15 \\
Athens & $37.90^{\circ}$ & December 1-March 15 & May 1-October 15 \\
\hline
\end{tabular}

The case study room has dimensions of $4 \mathrm{~m}$ by $4 \mathrm{~m}$ in plant and $3 \mathrm{~m}$ in height. The window opening is placed at the center of one of the walls at $0.9 \mathrm{~m}$ from the floor with the width of $1.3 \mathrm{~m}$ and the height equal to $1.55 \mathrm{~m}$; its surface is equal to $2 \mathrm{~m}^{2}$ corresponding to $1 / 8$ of the floor area. In the case in which the window was constituted by a French door, the dimensions are $1.3 \mathrm{~m}$ in width and $2.45 \mathrm{~m}$ in height. It is assumed that the room is located on the second floor - the height of the room floor from the road level is $6.7 \mathrm{~m}$ - of a four story building, $13 \mathrm{~m}$ high. Three walls of the room and the two horizontal partitions are considered adiabatic. The fourth wall, in which the window is inserted, is considered as 
an outward heat dispersive surface. The energy behavior of the room in different orientations has been analyzed. The sample room used for the calculations is represented in Figure 3. The building envelope characteristics are typical of a post Second World War Italian residential architecture. The basic configuration of the room presents a mixed masonry external wall, plastered on both sides, of a $0.47 \mathrm{~m}$ total thickness. The window is single glazed with $3 \mathrm{~mm}$ thick panes and the wooden frame is $50 \mathrm{~mm}$ thick, corresponding to $20 \%$ of the surface of the window. Table 4 shows main thermal performances of the external wall and of the window.

Figure 1. Monthly mean values of daily maximum, minimum and mean dry bulb temperature $\left(\theta_{\mathrm{bs}}\right)$ for Berlin $(\mathbf{A})$, Milan (B), Florence $(\mathbf{C})$, Athens (D).

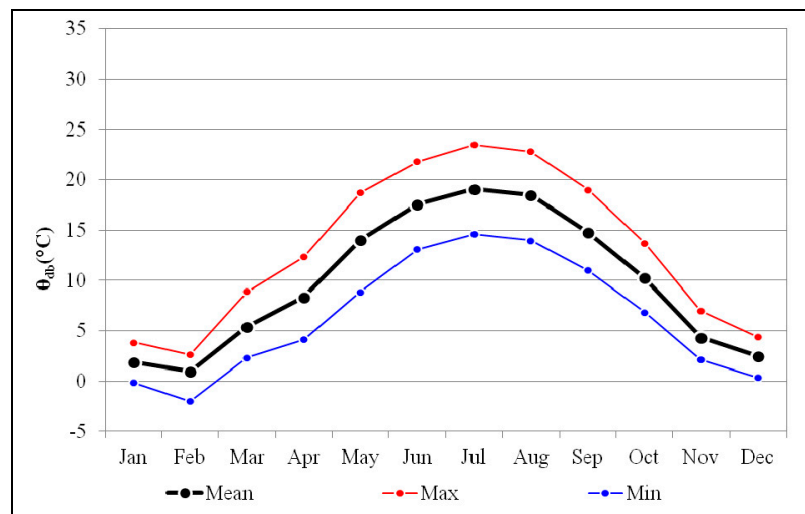

(A)

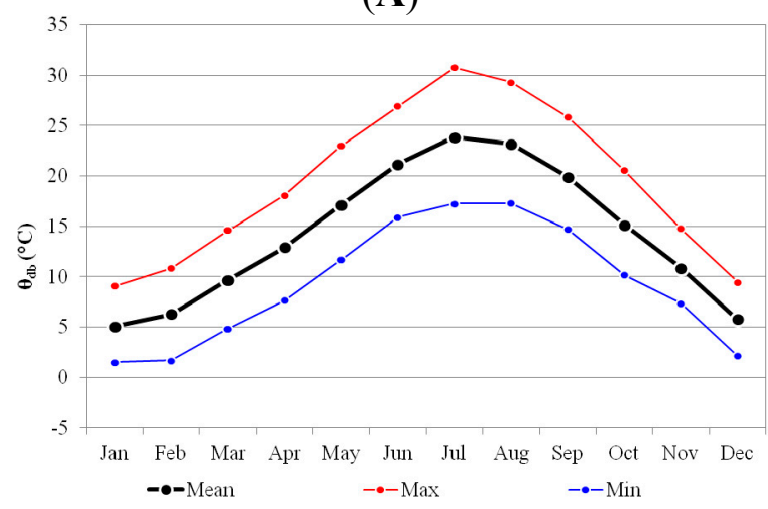

(C)

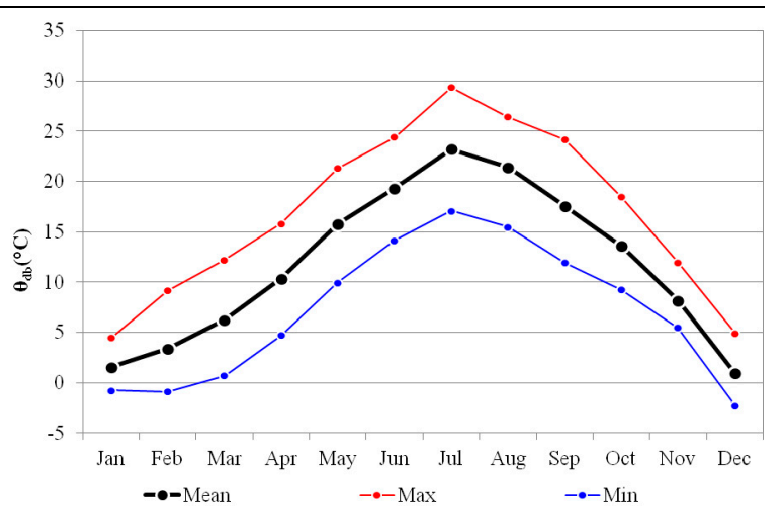

(B)

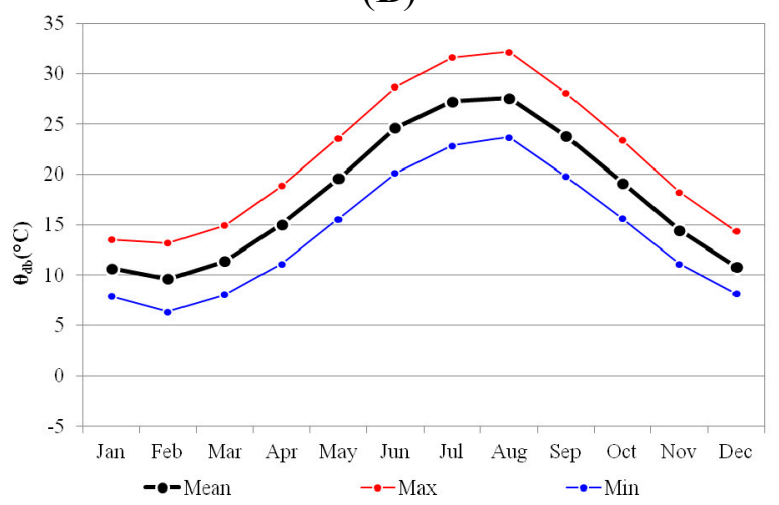

(D)

Appropriate performance indicators - defined by regulations or conventionally applied - have been identified in order to evaluate different refurbishment strategies for the achievements of energy efficiency and thermal sensation requirements: winter solar gains in $\mathrm{kWh}\left(\mathrm{Q}_{\mathrm{sw}}\right)$, summer solar gains in $\mathrm{kWh}\left(\mathrm{Q}_{\mathrm{ss}}\right)$, reduction factor of winter solar gains in $\%\left(\mathrm{~F}_{\mathrm{w}}\right)$ and reduction factor of summer solar gains in $\%\left(F_{s}\right)$, operative temperature in ${ }^{\circ} \mathrm{C}\left(\theta_{0}\right)$, hours outside the upper limit of $\theta_{\mathrm{o}}$ in $\%$.

$\mathrm{Q}_{\mathrm{sw}}$ and $\mathrm{Q}_{\mathrm{ss}}$ represent short-wave beam and diffuse solar radiation transmitted through the window's glass and integrated, on sub-hourly base, over the heating and cooling period. $\mathrm{F}_{\mathrm{w}}$ and $\mathrm{F}_{\mathrm{s}}$ are calculated as the complement to the unity of the ratio of the solar gains transmitted through the glass on an hourly basis, respectively in winter $\mathrm{Q}_{\mathrm{sw}}$ or in summer $\mathrm{Q}_{\mathrm{ss}}$, to those of the existing building. These indicators can be used to compare the solar gains reduction effectiveness over a building with or without the adoption of solar shading devices. As for the cooling season, the hours outside the upper limit of $\theta_{0}$ represent the percentage of hours when the operative temperature is outside the upper limit 
$\left(\theta_{i, \max }\right)$ recommended in EN 15251 Annex A.2 [28] for new or renovated buildings without mechanical cooling systems - category II, corresponding to a normal level of expectation.

Figure 2. Monthly values of direct and diffuse solar irradiation for Berlin (A), Milan (B), Florence (C), Athens (D).

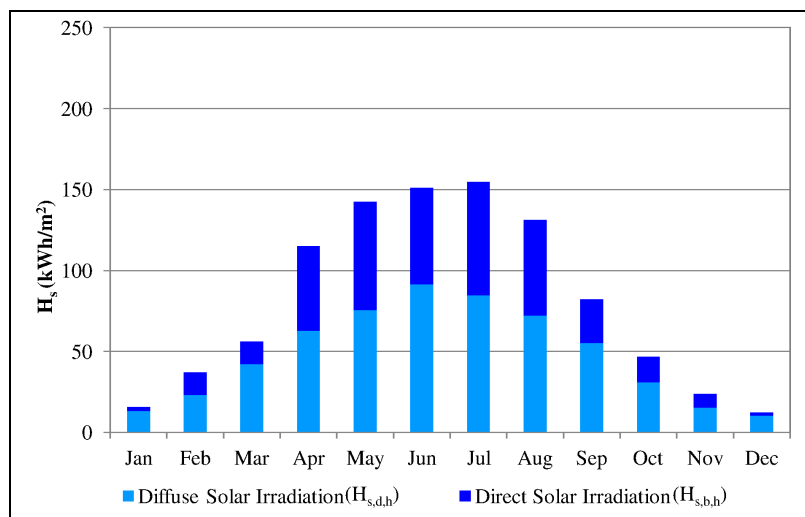

(A)

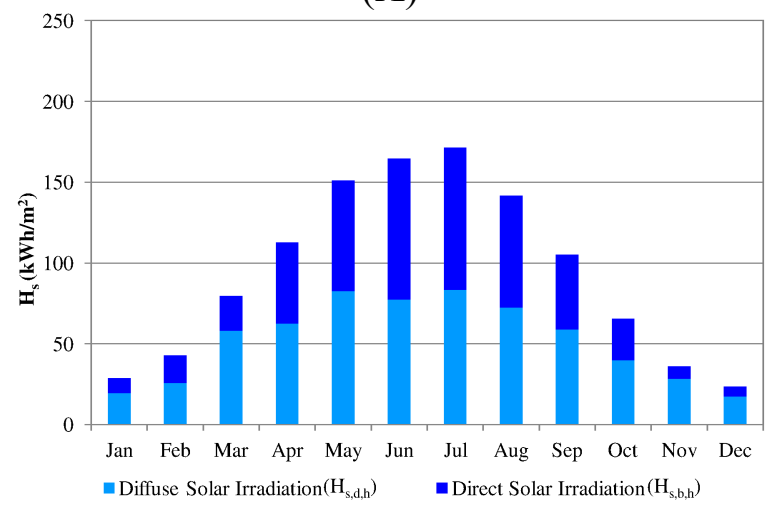

(C)

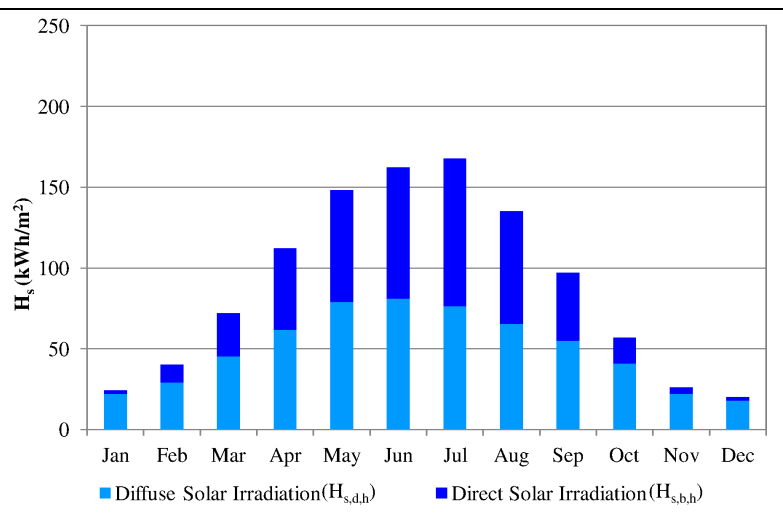

(B)

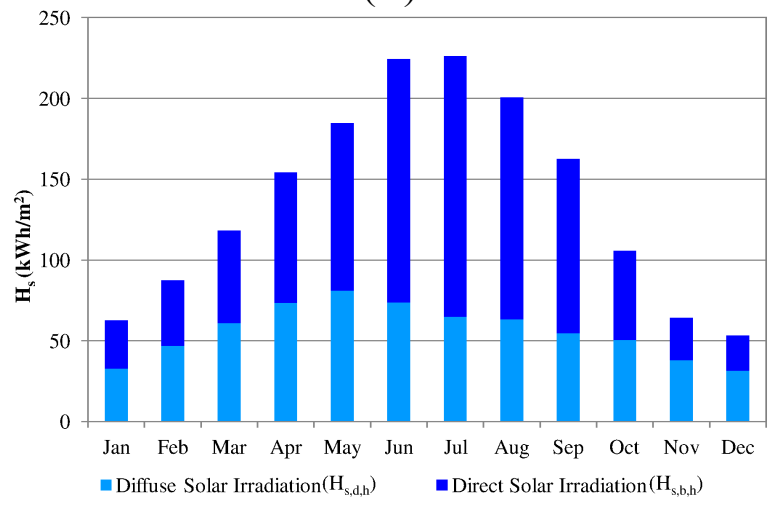

(D)

Figure 3. Plan and section of the case study.
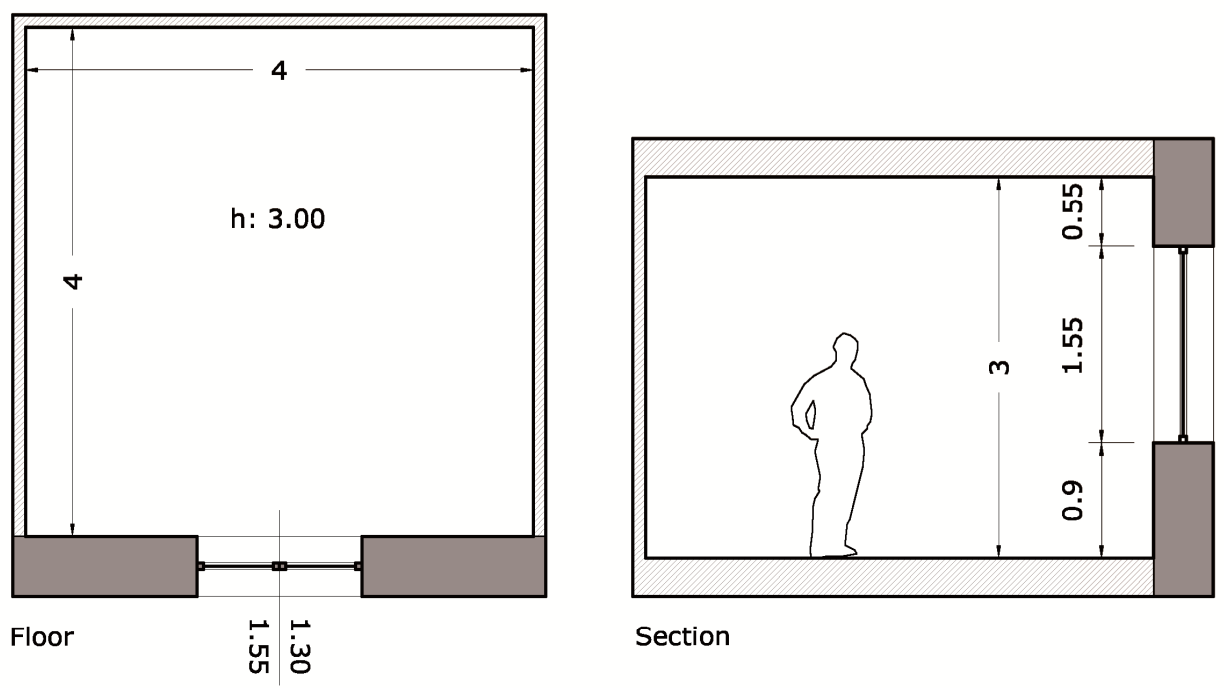

Section 
Table 4. Main thermal performances of the external wall and the window of the case study.

\begin{tabular}{lc}
\hline Performances of the external wall & \\
Thermal transmittance $(\mathrm{U})$ & $1.45 \mathrm{~W} / \mathrm{m}^{2} \mathrm{~K}$ \\
Periodic thermal transmittance $\left(\mathrm{Y}_{\mathrm{IE}}\right)$ & $0.152 \mathrm{~W} / \mathrm{m}^{2} \mathrm{~K}$ \\
Phase shift $(\varphi)$ & $14.19 \mathrm{~h}$ \\
\hline Performances of the window & \\
Thermal glass transmittance $\left(\mathrm{U}_{\mathrm{g}}\right)$ & $5.8 \mathrm{~W} / \mathrm{m}^{2} \mathrm{~K}$ \\
Thermal frame transmittance $\left(\mathrm{U}_{\mathrm{f}}\right)$ & $2.4 \mathrm{~W} / \mathrm{m}^{2} \mathrm{~K}$ \\
Thermal window transmittance $\left(\mathrm{U}_{\mathrm{w}}\right)$ & $5.33 \mathrm{~W} / \mathrm{m}^{2} \mathrm{~K}$ \\
Glass solar factor $(\mathrm{g})$ & 0.87 \\
\hline
\end{tabular}

In [14] lighting and acoustic characteristics of the case study and of the different refurbishment strategies have been described and lighting and acoustic performance have been also evaluated.

The methodology of analysis hypothesized in this study refers to the most frequent sequence of the building energy refurbishment that can be found in several practical cases (Table 5): in existing buildings the replacement of windows $(49 \%)$ is followed by the improvement in the energy performance of opaque vertical envelope $(30 \%)$.

Table 5. Summary of the simulations phases performed in this study.

\begin{tabular}{lll|}
\hline \multicolumn{1}{c}{ Phase A } & Phase B & Phase C \\
\hline $\begin{array}{l}\text { Basic configuration of the case } \\
\text { study room, representing a typical } \\
\text { post World War II Italian } \\
\text { residential architecture }\end{array}$ & $\begin{array}{l}\text { Replacement of existing window } \\
\text { with high energy performance } \\
\text { one. }\left(\mathrm{U}_{\mathrm{w}}=1.77 \mathrm{~W} / \mathrm{m}^{2} \mathrm{~K}, \mathrm{~g}=0.58\right)\end{array}$ \\
\hline
\end{tabular}

Starting from the performance evaluation of the Phase A, the study provides the assessment of the following retrofit strategies:

- Phase B: replacement of existing window with high energy performance one;

- Phase C: introduction of different solar gain control systems.

In particular in this paper results of Phase $\mathrm{C}$, compared with those of phases $\mathrm{A}$ and $\mathrm{B}$, are presented and discussed.

The selection criteria for solar gain control systems (Table 6) follow the requirements of reduction of energy consumption in summer and winter and the achievement of adequate thermal comfort level, ensuring visual perception of the outdoor [3]. In a previous research [14] different sun shading devices and solar control glasses were analyzed and the most commonly used in residential buildings were identified and evaluated, excluding those configurations overly intrusive or hardly feasible for the 
building refurbishment. In this study, in order to guarantee direct performances comparison of some of these systems, their geometric characteristics have been uniformed regarding: slat width and thickness, slat separation and slat tilt. The tilt of the slats, equal to $0^{\circ}$ and perpendicular to glass, was chosen from among those which ensured a level of annual average illuminance greater than $2001 \mathrm{x}$.

Among possible materials available on the market, for weight and installation advantages, aluminum slats have been chosen; the product presents a white color that reflects incident solar radiation, both direct and diffuse, with hemispherical uniform distribution-IR hemispherical and visible transmittance $=0.0$, visible reflectance $=0.8$ and hemispherical emissivity $=0.9$.

Table 6. Schedule of types of screen analyzed in Phase C.

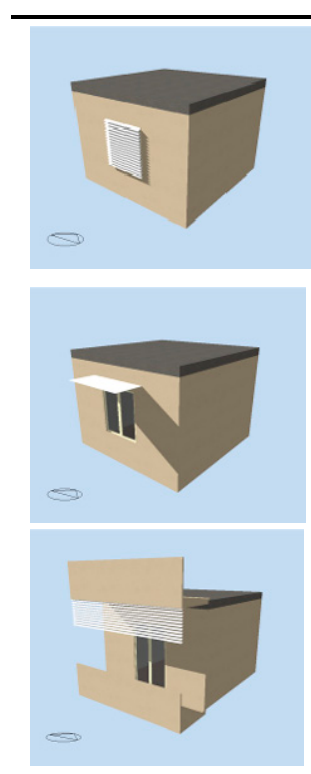

\section{C1-Venetian Blinds (tilting: $0^{\circ}$ )}

Slats dimensions: $0.08 \mathrm{~m}$ depth, $1.3 \mathrm{~m}$ width

Slats separation: $0.08 \mathrm{~m}$

Slats thickness: $0.002 \mathrm{~m}$

Blind to glass distance: $0.1 \mathrm{~m}$

\section{2-Fix opaque horizontal overhang}

Projection: $0.8 \mathrm{~m}$

Width: $1.9 \mathrm{~m}$

Vertical offset from the window top: $0.2 \mathrm{~m}$

\section{3 - Blind integrated with balcony (tilting: $0^{\circ}$ )}

Slats dimensions: $0.08 \mathrm{~m}$ depth, whole facade width

Slats separation: $0.08 \mathrm{~m}$

Slats thickness: $0.002 \mathrm{~m}$

Devices height: $0.8 \mathrm{~m}$

Balcony depth: $1.2 \mathrm{~m}$

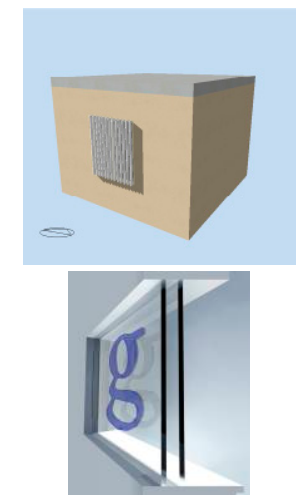

C 4-Blind with vertical slats (tilting: $0^{\circ}$ )

Slats dimensions: $0.08 \mathrm{~m}$ depth, $1.55 \mathrm{~m}$ high

Slats separation: $0.08 \mathrm{~m}$

Slats thickness: $0.002 \mathrm{~m}$

Blind to glass distance: $0.1 \mathrm{~m}$

C 5-Solar control glass

$\mathrm{g}=0.21$

$\tau_{\mathrm{v}}=0.4$

$\mathrm{U}_{\mathrm{g}}=1.60 \mathrm{~W} / \mathrm{m}^{2} \mathrm{~K}$

$\mathrm{U}_{\mathrm{w}}=1.77 \mathrm{Wm}^{2} \mathrm{~K}$

\section{Results and Discussion}

The presence of glass surfaces ensures in winter favorable thermal gains; however, in summer it may cause indoor overheating. Recently, the replacement of windows in existing buildings has become common practice, thanks to tax incentives offered for example in Italy — with the Law ${ }^{\circ} 296 / 2006$ - , to the ease of implementation and to the synergy of positive effects that the intervention may produce-for example the improvement in the acoustic performance of the facade. This action presents a great deal 
of technical feasibility since it rarely involves outside interventions, for example, with scaffolding, and does not interfere seriously with the activities inside rooms.

An additional factor to be taken into account during the replacement of windows is the influence that the position of the frame has with respect to the facade (at the outer edge, on the center line, at the inner edge) can have on solar loads and consequently on need for air conditioning. For instance, for the location of Berlin, as shown in Figure 4A, the position of the window with respect to the facade involves, in the transition from the inner to the outer edge, an increase of winter solar gain between $50 \%$ (south orientation) and $61 \%$ (east orientation) and an increase of summer solar gains between $48 \%$ (west orientation) and $77 \%$ (south orientation). For the location of Athens, as shown in Figure 4D, the position of the window with respect to the facade involves, in the transition from the inner to the outer edge, an increase of winter solar gain between 53\% (south orientation) and $62 \%$ (east orientation) and an increase of summer solar gains between $42 \%$ (west orientation) and $71 \%$ (south orientation).

Figure 4. Influence of the orientation and the window position respect to the facade on winter $\left(\mathrm{Q}_{\mathrm{sw}}\right)$ and summer $\left(\mathrm{Q}_{\mathrm{ss}}\right)$ solar gains per unit of floor area $(\mathbf{A})$, for the locations of Berlin (A), Milan (B), Florence (C) and Athens (D).

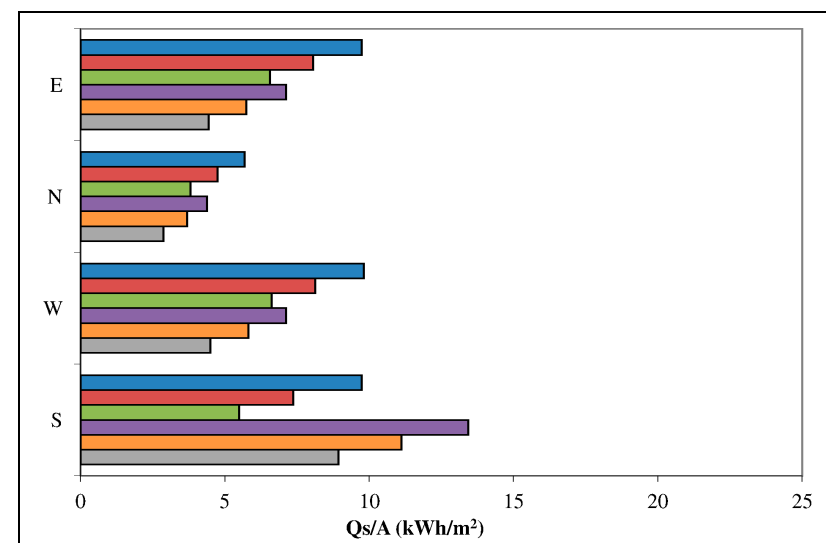

(A)

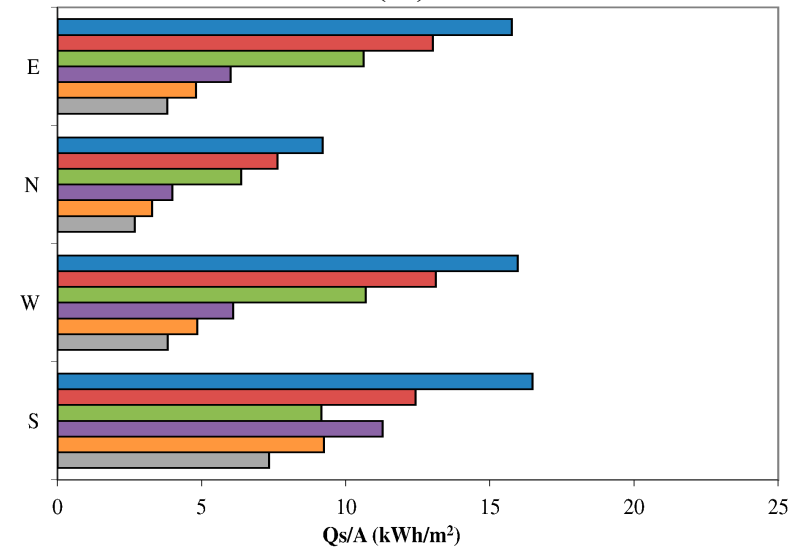

(C)

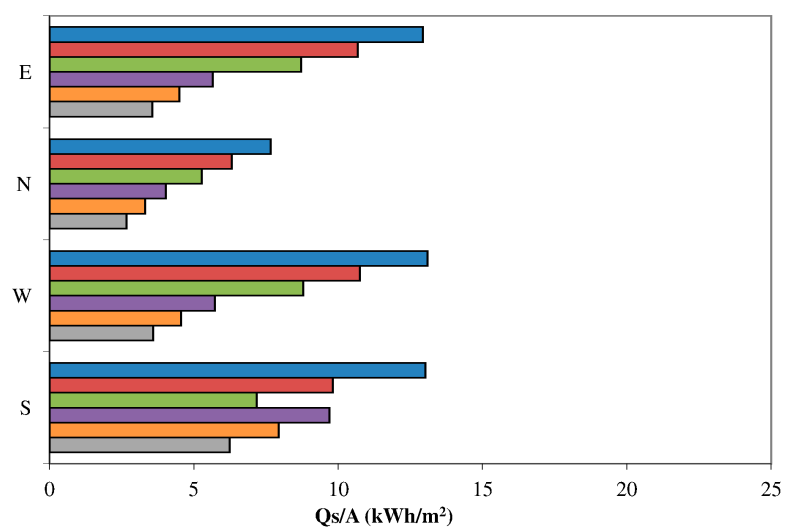

(B)

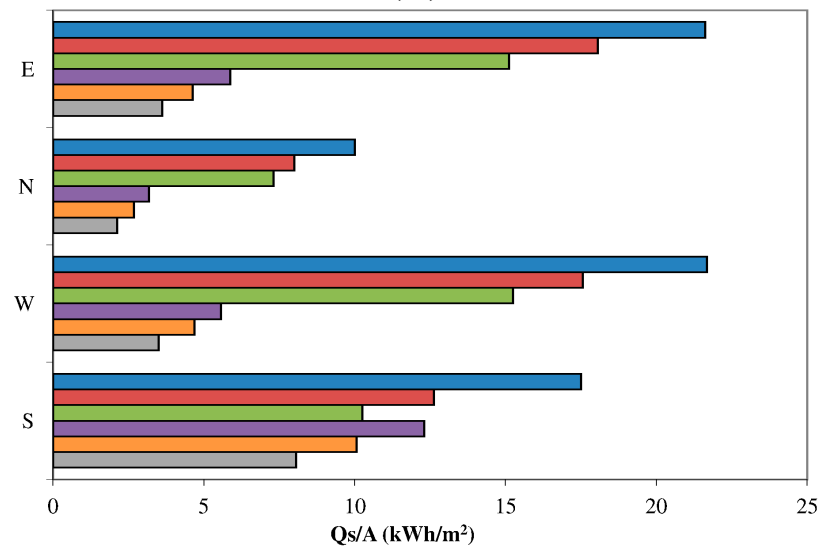

(D)

$\square \mathrm{Qs,s} / \mathrm{A}$ - outer edge $\square \mathrm{Qs,s} / \mathrm{A}$ - center line $\square \mathrm{Qs,s} / \mathrm{A}$ - inner edge $\square \mathrm{Qs,w} / \mathrm{A}$ - outer edge $\square \mathrm{Qs,w} / \mathrm{A}$ - center line $\square \mathrm{Qs,w} / \mathrm{A}$ - inner edge

The different positioning of the frame relative to the facade profile leads to the resolution of some technological details which concern mainly the relation with the thermal insulation, the reduction of 
thermal bridges that might ensue, the presence or the absence of space where to place the shading system, the proper sealing on the frame/masonry coupling in order to prevent infiltration of air and noise. The installation procedures of windows must attend to the main requirements of control of thermal bridges [29] and control of sound transmission [30] through the window framing and the wall system. Both of those requirements have to be fulfilled otherwise good energy saving windows may have their performance diminished as a result of a poorly proceeded installation. The best solutions, with values of linear thermal transmittance $(\psi) \leq 0.20 \mathrm{~W} /(\mathrm{mK})$, are those with the frame resting directly to the insulating layer.

In Italy, the Law $\mathrm{n}^{\circ} 311 / 2006$ has given greater importance to the need for control of solar radiation in summer conditions, forcing the designer to consider the problem of verifying the risk of indoor overheating due to unshielded glass surfaces, especially for West and South orientation.

In Figures 5 and 6, respectively for the exposure South and West, for the four locations of analysis, is the reduction factor of summer solar gains derived from the comparison with Phase A. Considering only the summer period, the configuration more effective in reducing solar gain is the $\mathrm{C} 5$ for both openings facing South and West. For the southern orientation, other types have slightly different results between them-of about 5\%-, giving best performance for configurations $\mathrm{C} 1$ and $\mathrm{C} 3$. Regarding West orientation, the differences between the various strategies are greater —about $15 \%$ - with good results obtained by the configurations $\mathrm{C} 1$ and $\mathrm{C} 4$.

Figure 5. Reduction factor of summer solar gains $\mathrm{F}_{\mathrm{s}}$ for different shading systems selected for the four locations, relatively to South orientation.

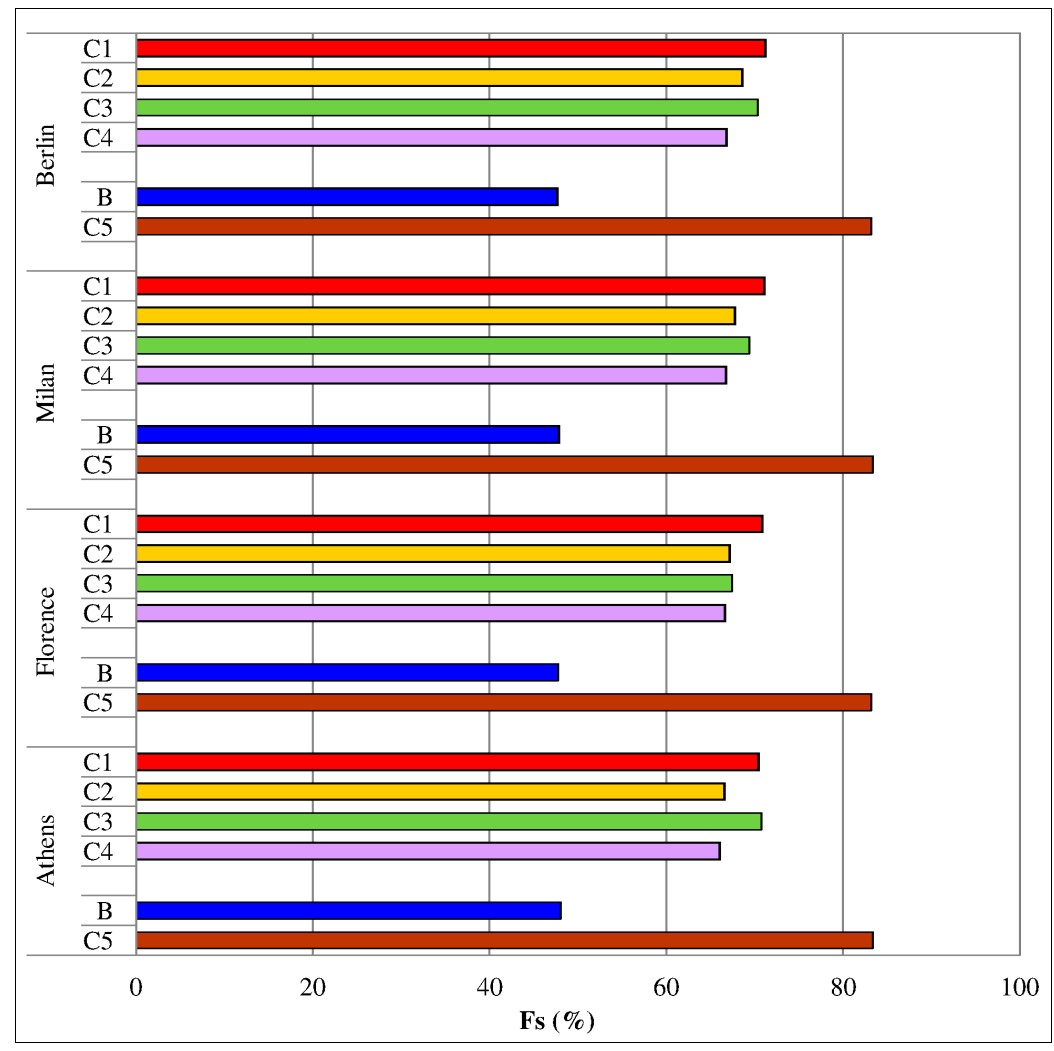


Figure 6. Reduction factor of summer solar gains $F_{\mathrm{s}}$ for different shading systems selected for the four locations, relatively to West orientation.

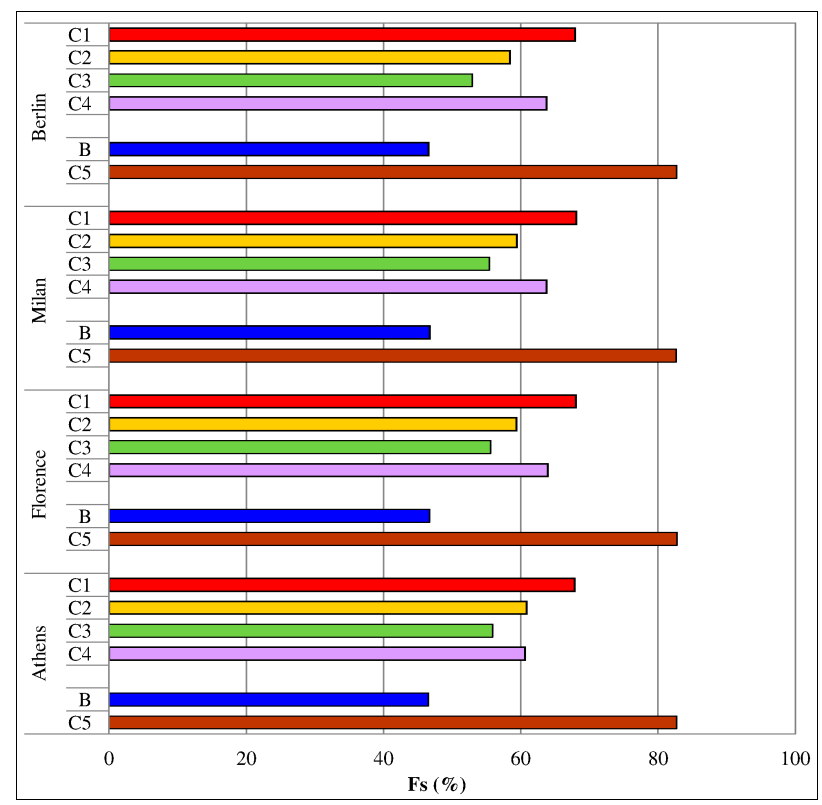

In general, among the several parameters to take into consideration in the choice of a control system of the solar radiation, the capability of the shading system to reduce thermal loads in summer and to allow solar gains in winter must be taken into account. This feature can be analyzed by comparing the difference between $\mathrm{F}_{\mathrm{s}}$ and $\mathrm{F}_{\mathrm{w}}(\Delta \mathrm{F})$; in substance, a shading system can be considered much more effective if it has a high value of $F_{s}$ and a corresponding low value of $F_{w}$, then the higher the value $\Delta F$ and the greater the shading effectiveness. In Figures 7 and 8, respectively for the exposure South and West, for the four locations of analysis, is reported the parameter $\Delta \mathrm{F}$ coming from the comparison with Phase A, expressed as a percentage.

Figure 7. Difference between $F_{s}$ and $F_{w}(\Delta F)$ for different shading systems selected for the four locations, relatively to South orientation.

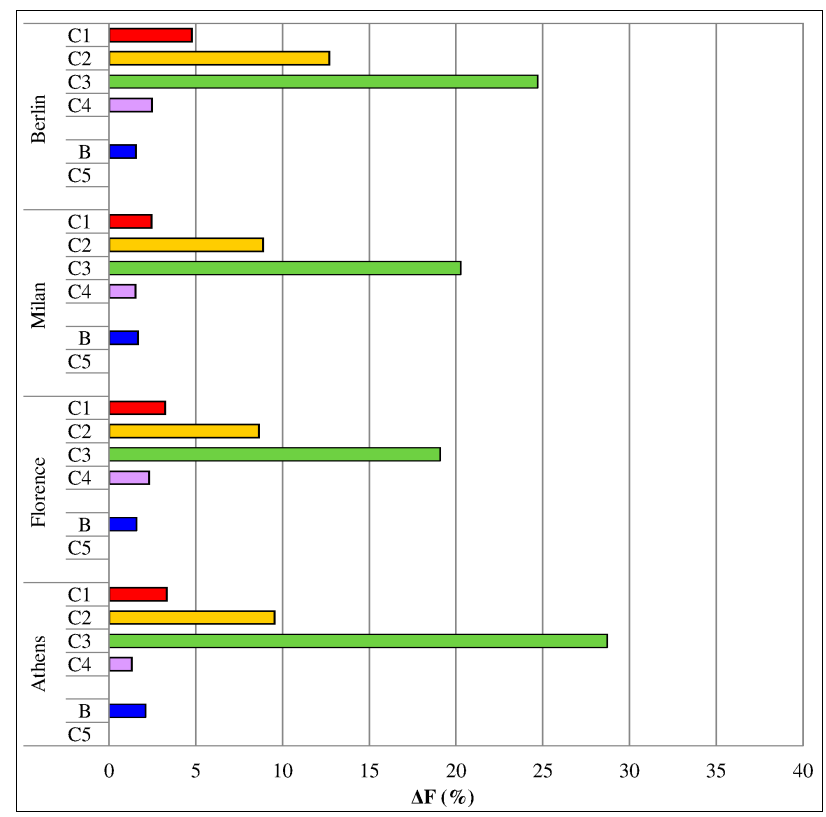


Figure 8. Difference between $F_{s}$ and $F_{w}(\Delta F)$ for different shading systems selected for the four locations, relatively to West orientation.

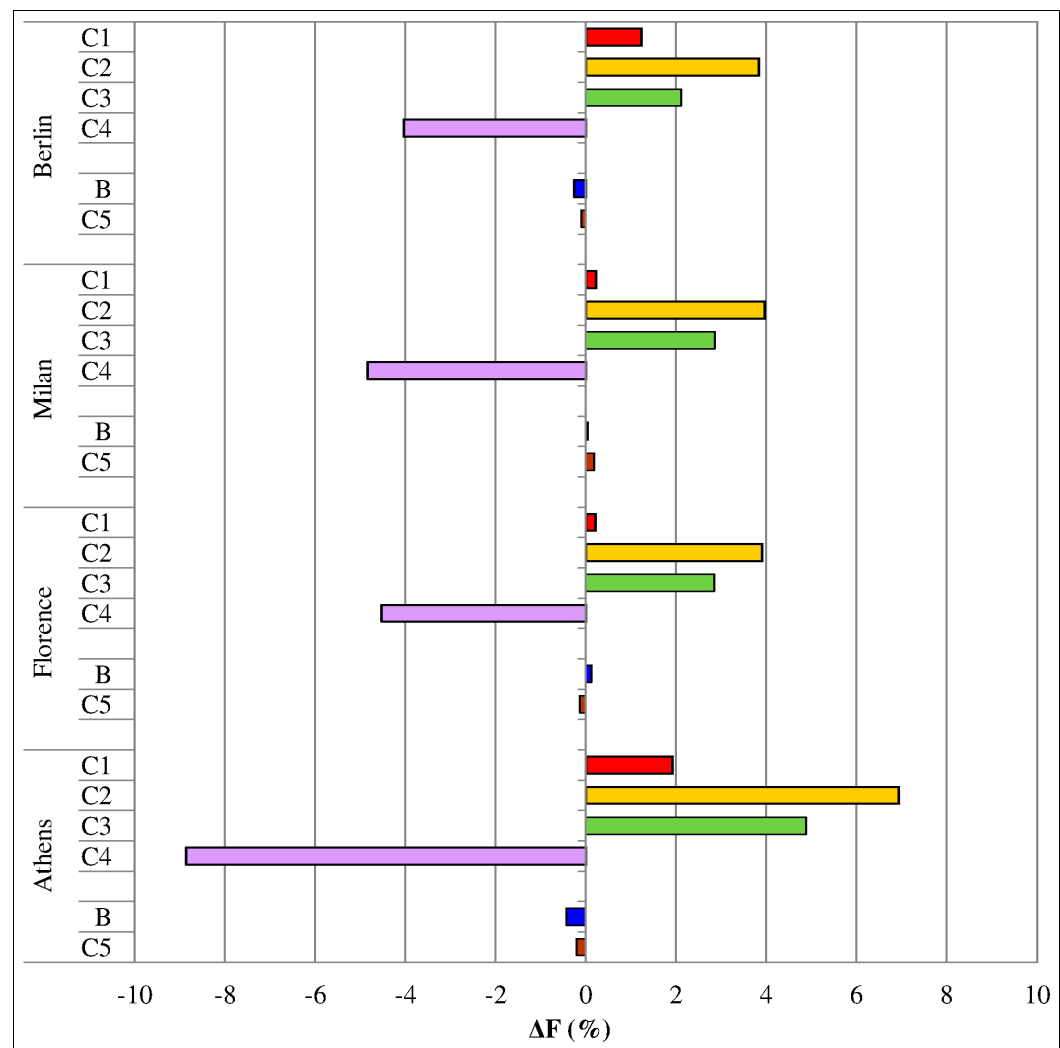

For all the locations analyzed, taken as a reference of the climatic variability of the European territory, for the south orientation the following observations based on the above mentioned $\Delta \mathrm{F}$ value can be made:

- The insertion of a shading system (C3) in an existing balcony or the addition of a new balcony adjacent to the existing building, as well as allowing a greater enjoyment of the living spaces, involves the best results, especially when it is combined with horizontal blinds tilted of $0^{\circ}$ in southern locations.

- The overhang opaque horizontal perpendicular to the facade (C2) has good results and far lower than $\mathrm{C} 3$ system - on the order of $50 \%$.

- Venetian blind (C1) is not so performing when considered always closed during the year.

- The solar control glasses have the same reduction of solar gains both in summer and in winter, so their use should also be evaluated as a function of the intended use of the property. This strategy can be considered a valuable alternative to the use of external shielding in situations in which the insertion in the facade of foreign elements to the original morphology of the building is problematic - such as for example in the case of historical buildings and in historical centers, etc.- or technically complex.

Regarding the western orientation, in winter, all shading devices analyzed penalize the solar gains more than the same applied to south orientation; in particular, blinds with vertical slats $\mathrm{C} 4$ have a reduction factor of winter solar gains $\mathrm{F}_{\mathrm{w}}$ bigger than the reduction factor of summer solar gains $\mathrm{F}_{\mathrm{s}}$. 
To ensure more benefits, it might be useful to combine these shading devices with a building automation system that manages the opening in a dynamic way, in relation to incident solar radiation. Thus, visual comfort can be effectively controlled to avoid glare effects inside the building. In particular, regarding South and West exposure, in Figure 9 the reduction seasonal factors $F_{w}$ and $F_{s}$ are compared for three different configurations of the venetian blind:

- Always unpacked in both summer and winter (C1).

- Automatically packed only in summer when incident solar radiation on the window $\left(\mathrm{I}_{\text {sol }}\right)$ is less than $200 \mathrm{~W} / \mathrm{m}^{2}$ and completely packed in winter (C1/200W-s).

- Automatically packed throughout the year when $\mathrm{I}_{\text {sol }}$ is less than $200 \mathrm{~W} / \mathrm{m}^{2}$ (C1/200W-y).

This analysis emphasizes the highly efficient behavior of the external venetian when it is considered completely packed in winter season $(\mathrm{C} 1 / 200 \mathrm{~W}-\mathrm{s})$.

Figure 9. Reduction seasonal factors $\left(F_{w}\right.$ and $\left.F_{s}\right)$ for different configurations of the venetian blind, relatively to South and West orientation.

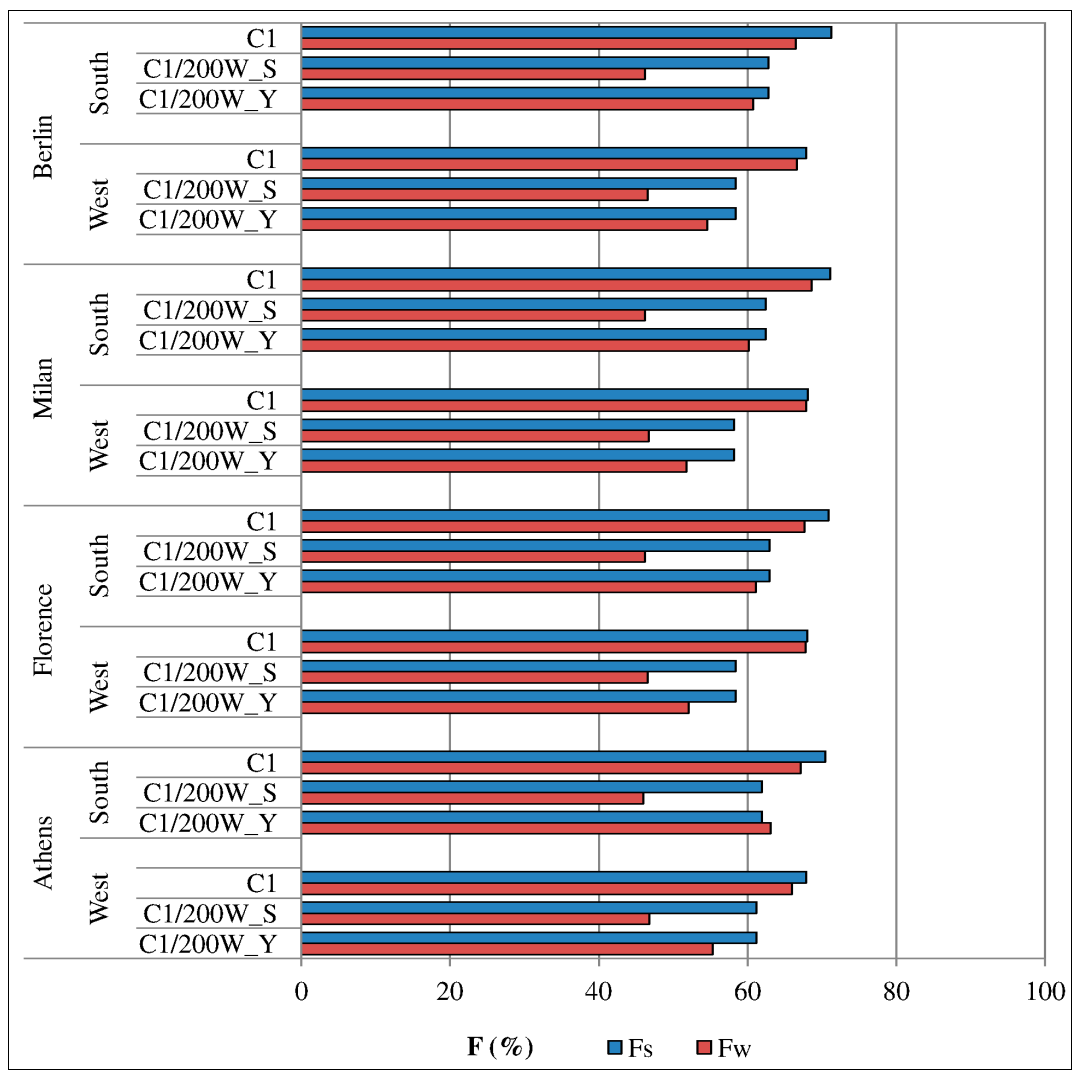

Evidently, the solar gain reduction seasonal factors cannot be the only criteria that guide the designer in choosing the shading strategy, since it does not take into consideration a number of fundamental questions, such as: user's comfort, cost, technical feasibility of the intervention and the architectural integration with the building.

In particular, the thermal sensation of the occupants can also be estimated by means of the operative temperature. For all the locations and for the southern orientation, in order to assess the implications of the thermal sensation of some solar control systems, Figure 10 shows the hours outside the $\theta_{\mathrm{o}}$ upper 
limit $\left(\theta_{\mathrm{i}, \mathrm{max}}\right)$ in the cooling season and Figure 11 shows the trend of the $\theta_{\mathrm{o}}$ inside the case study room in a critical summer day (July 23).

Figure 10. Hours outside $\theta_{\mathrm{i} \max }(\%)$ in the cooling season for different solar shading devices, for Berlin (A), Milan (B), Florence (C) and Athens (D).

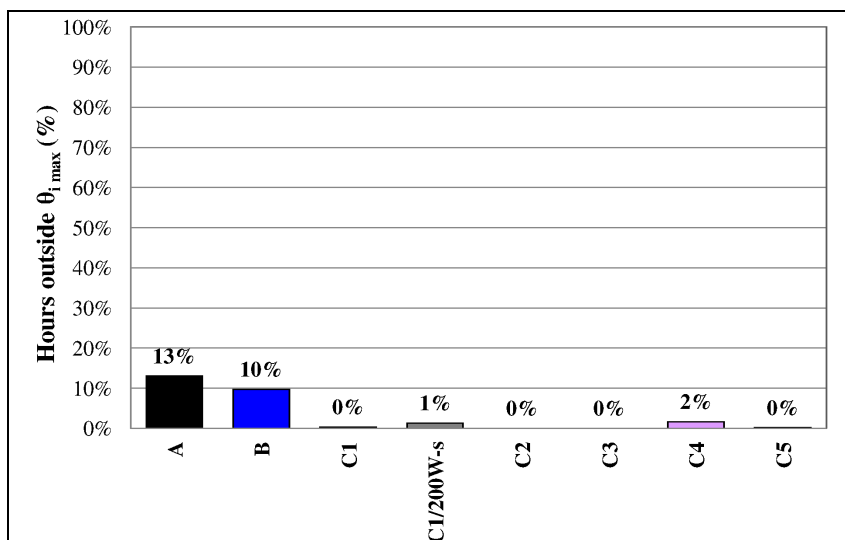

(A)

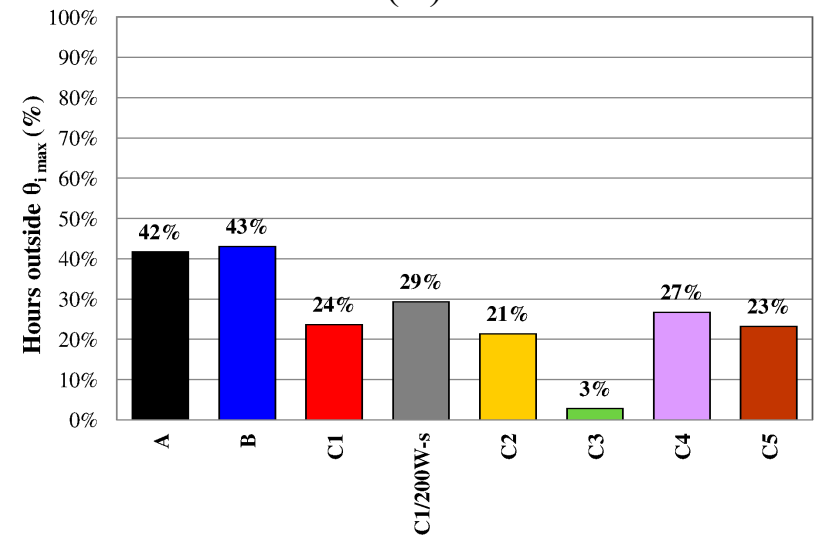

(C)

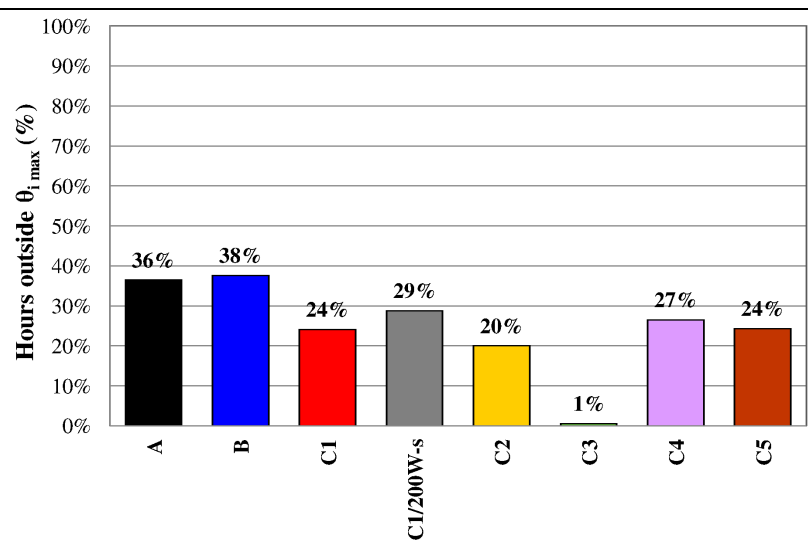

(B)

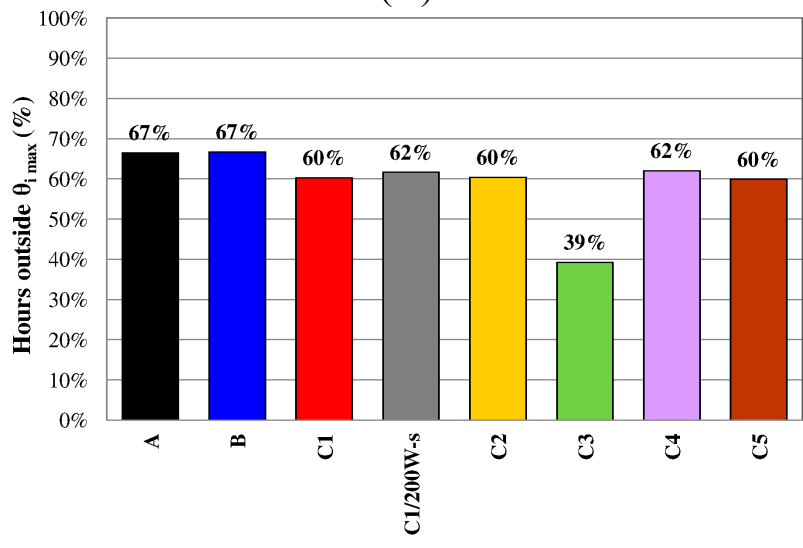

(D)

For this analysis, besides the the definition of room geometry and building components materials, other input data were considered. Internal gain for occupants and artificial lighting is $5 \mathrm{~W} / \mathrm{m}^{2}$ constant all day long; infiltration and ventilation rate are two air changes per hour-half of the window open - from 7:00-9:00 and from 18:00-23:00, and 0.1 air changes per hour-infiltration only—in the remaining hours; the occupants are present from 18:00-9:00 and the room is not provided with any cooling equipment. In Figures 10 and 11, the following configurations are compared with Phase A and Phase B: insertion of different sunshade composed by external venetian blinds with an angle of $0^{\circ}$ (C1), the same venetian blinds with dynamic control (C1/200W-s), fix opaque horizontal overhang (C2), shielding system integrated on the $1.2 \mathrm{~m}$ balcony and blinds with an angle of $0^{\circ}(\mathrm{C} 3)$, sunscreen with vertical fixed blinds tilted $0^{\circ}(\mathrm{C} 4)$ and solar control glass with $\mathrm{g}=0.21$ (C5).

Figure 10 reveals that the replacement of the window only, without any shading devices, slightly affects the hours outside $\theta_{\mathrm{i} \text {,max }}$, even if the $\mathrm{g}$ value of the new glazing is decreased. For all the locations, the solar shading devices and the solar control glass assessed highly affect the hours outside $\theta_{i, \text { max }}$. Blinds integrated with balcony of $1.2 \mathrm{~m}$ depth (C.3) mostly reduce hours outside $\theta_{\mathrm{i}, \max }$; for Berlin, Milan and Florence this shading device is able to reduce the indoor overheating up to negligible values, while for Athens the hours outside $\theta_{i, \max }$ reduction is of about $40 \%$, compared with Phase $\mathrm{A}$, 
due to high outdoor temperatures. The effect of the automatic control system of venetian blinds even if slightly increasing the hours outside $\theta_{\mathrm{i}, \max }$ can guarantee a better visual comfort and daylighting.

Figure 11. Operative temperature trend within the room south-facing located in Berlin (A), Milan (B), Florence (C) and Athens (D) for different sunshade systems in a critical summer day, July 23.

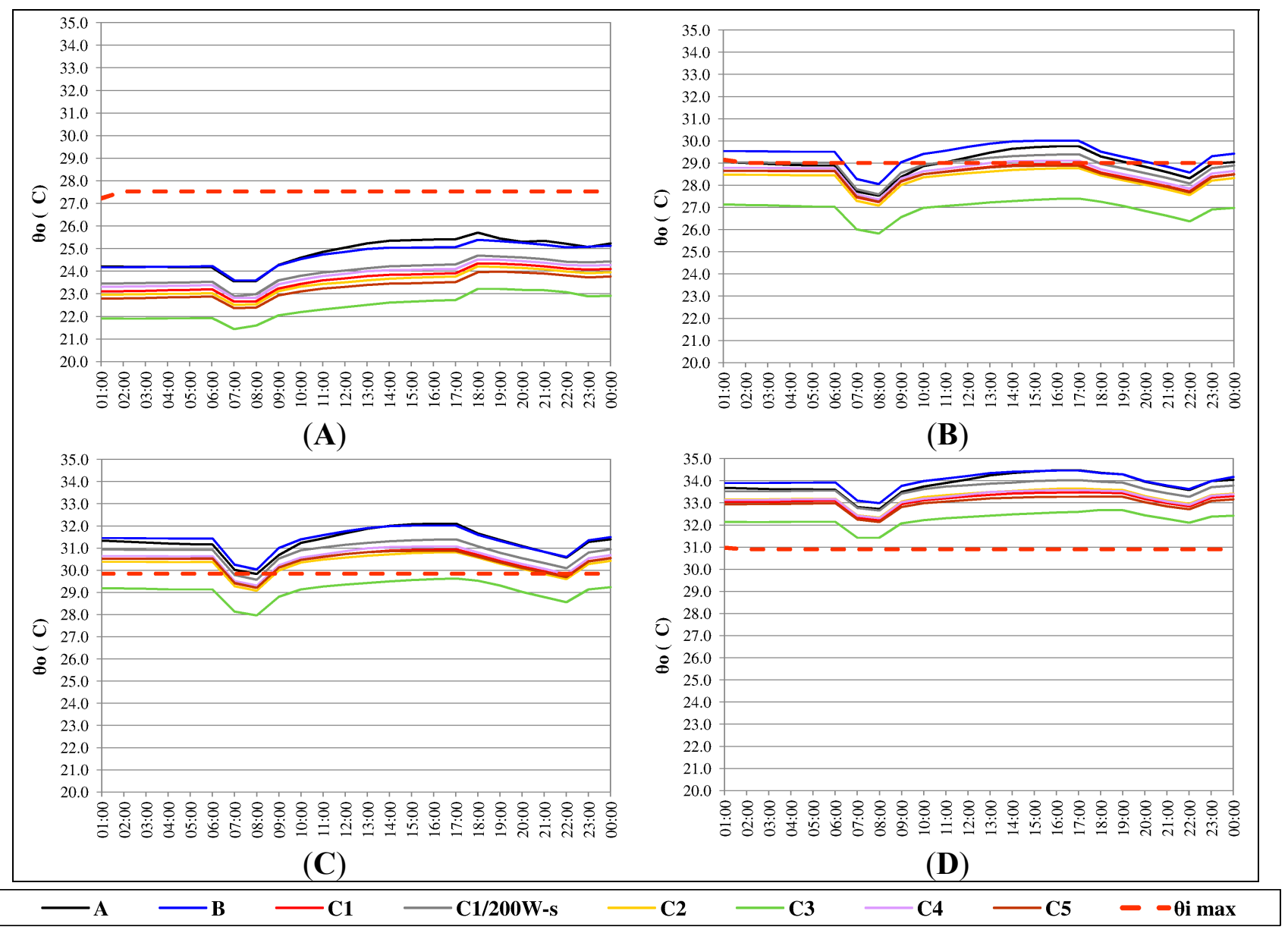

\section{How to Choose a Solar Shading Device}

The choice of a proper solar control system should be based, besides on energy performance, on the aspects regarding visual, thermal and acoustic comfort, technical feasibility, easiness of use and of maintenance.

In Table 7, the main types of solar control systems are summarized and simply evaluated according to their capacity to contribute to the various benefits and functions, for a rough, first orientation in order to provide preliminary guidelines for choosing the types most suitable for the specific case and valid for all the selected cities (reworked from [3]). 
Table 7. Evaluation of different types of solar radiation control systems.

\begin{tabular}{|c|c|c|c|c|c|c|c|c|c|}
\hline Type of solar shading & 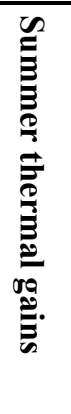 & 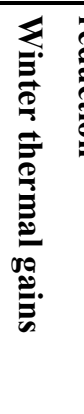 & 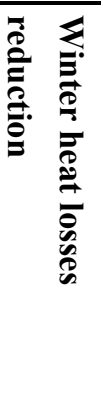 & 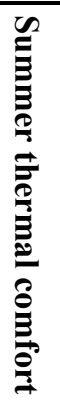 & 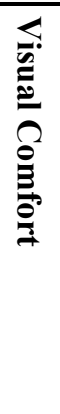 & 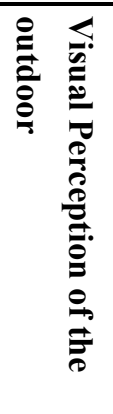 & 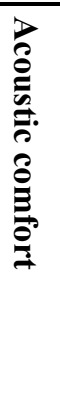 & 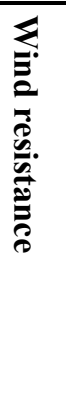 & 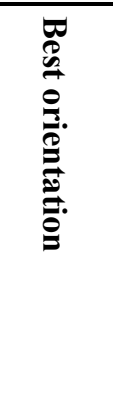 \\
\hline \multicolumn{10}{|c|}{ External position with respect to the frame } \\
\hline Horizontal Sunscreen & ++ & ++ & - & + & + & ++ & - & ++ & $\mathrm{S}$ \\
\hline Fixed Overhang & ++ & ++ & - & + & + & ++ & - & ++ & $\mathrm{S}$ \\
\hline Fixed screens & ++ & + & - & + & + & + & - & ++ & S-E-W \\
\hline Horizontal Sunscreen fixed blades & ++ & o & - & ++ & o & o & - & ++ & $\mathrm{S}$ \\
\hline Vertical Sunscreen fixed blades & + & o & - & + & 0 & o & o & ++ & E-W \\
\hline Venetian blinds & ++ & ++ & o & ++ & + & o & o & + & S-E-W \\
\hline Operable shading & ++ & ++ & + & ++ & + & o & + & ++ & S-E-W \\
\hline Roller Blinds & ++ & ++ & ++ & + & + & - & + & ++ & S-E-W \\
\hline \multirow{4}{*}{ Sliding arm awning } & + & ++ & - & + & o & - & - & o & S-E-W \\
\hline & + & ++ & - & + & o & o & - & o & S-E-W \\
\hline & + & ++ & - & o & o & ++ & - & o & S-E-W \\
\hline & + & ++ & - & + & o & + & - & o & $\mathrm{S}$ \\
\hline \multicolumn{10}{|c|}{ Position in the cavity of the double glazing and solar control glass } \\
\hline Venetian blind & o & ++ & - & o & + & o & - & - & S-E-W \\
\hline Roller blind & o & ++ & - & o & o & - & - & - & S-E-W \\
\hline Solar control glass & ++ & - & - & ++ & o & ++ & - & - & S-E-W \\
\hline \multicolumn{10}{|c|}{ Inner position with respect to the window frame } \\
\hline Vertical Curtain & - & ++ & - & - & o & - & - & - & - \\
\hline Venetian blind & - & ++ & - & - & + & o & - & - & - \\
\hline
\end{tabular}

Legend: ++ Excellent; + Good; 0 Moderate; - Not relevant;E east; W west; S south

For all analyzed cities, in Table 8, the major aspects to be taken into account for the choice of the most appropriate shading system and the corresponding actions are reported (reworked from [14]).

In order to correctly choose a solar shading system, a global comparative analysis has to be carried out based on energy, acoustic and lighting performance, on technical feasibility and management. The results from this analysis, applied to the described case study for the location of Florence, are reported in the following data sheet (Table 9) where the type of the system and a 
synthetic evaluation - energy, day lighting and acoustic behavior - are summarized in a simple and plain way, addressed to designers.

Table 8. Aspects to consider for a proper solar shading system choice.

\begin{tabular}{|c|c|}
\hline Aspects to take into account & Corresponding specific actions \\
\hline Purposes of the intervention & $\begin{array}{l}\text { Solar radiation and summer heat load control, glare reduction, aesthetic and } \\
\text { functional rehabilitation, greenhouse effects control, thermal and acoustic } \\
\text { comfort improvement, etc. }\end{array}$ \\
\hline Historical Buildings and Landscape & $\begin{array}{l}\text { Evaluation of historic features of the building and the site, analysis of } \\
\text { architectural constraints, etc. }\end{array}$ \\
\hline Climatic location & $\begin{array}{l}\text { Parameters collection and acquisition expressing the climatic conditions of the } \\
\text { site (temperature, solar radiation, prevailing winds, etc.) }\end{array}$ \\
\hline Window Orientation & $\begin{array}{l}\text { Evaluation of seasonal variations in the incidence of solar radiation in relation to } \\
\text { the environment (presence of shadows, boundary conditions, albedo effect, etc.). }\end{array}$ \\
\hline $\begin{array}{l}\text { Position on the } \\
\text { facade }\end{array}$ & $\begin{array}{l}\text { Position of the elevation of the screen in relation to solar energy and acoustic } \\
\text { pressure, action of the winds, etc. }\end{array}$ \\
\hline Choice of the shielding system & $\begin{array}{l}\text { Type-fixed or mobile-, arrangement — horizontal or vertical—and tilt } \\
\text { of the flaps, blinds, blades of the screen. Thermal comfort, light and acoustic } \\
\text { performances of sunscreen. }\end{array}$ \\
\hline Technical feasibility & $\begin{array}{l}\text { Building typology and compatibility with the system chosen: appropriate } \\
\text { anchoring techniques, assembly and installation, etc. }\end{array}$ \\
\hline Management & Management and possibilities of operation, user friendliness, etc. \\
\hline Costs & Cost analysis of the type of screen, comprehensive of the installation costs. \\
\hline Costs of maintenance & $\begin{array}{l}\text { Analysis of maintenance costs in relation to the screen selected, easiness to } \\
\text { replace, availability of materials and spare parts, skilled manpower, etc. }\end{array}$ \\
\hline Costs/Performances analysis & $\begin{array}{l}\text { Costs/Performance final evaluation taking into account all the aspects } \\
\text { above examined. }\end{array}$ \\
\hline
\end{tabular}

The symbols in the data sheet express qualitative assessments-good, not relevant or not satisfactory-, associated to the screen typology. In particular, they express the relevance of the device in terms of the physical behavior response, with regard to the following requirements and performance indicators:

- Technical feasibility (TF): installation, need for skilled manpower, need for further building permits;

- Management (M): user's possibility to act on the effect of the shielding system, for instance by varying the angle of the blinds, easy maintenance, etc.;

- Seasonal solar gain reduction factors $\left(F_{w}, F_{s}\right)$ previously calculated ad assessed for south orientation of the windows: in particular, when $\mathrm{F}_{\mathrm{w}}$ is in the order of $20 \%$ or less, it is considered that the system does not affect the solar gains;

- Visual comfort (VC): takes into account the uniformity of illumination and the amount of natural light available [31];

- Sound insulation of facade expressed in $\mathrm{dB}\left(\mathrm{D}_{2 \mathrm{~m}, \mathrm{nT}, \mathrm{w}}\right)$ : in particular, it is considered "good" when the contribution of the system is at least greater than $1 \mathrm{~dB}[31]$. 
Table 9. Data sheet for different solar shading devices_-Synthetic comparative evaluation.

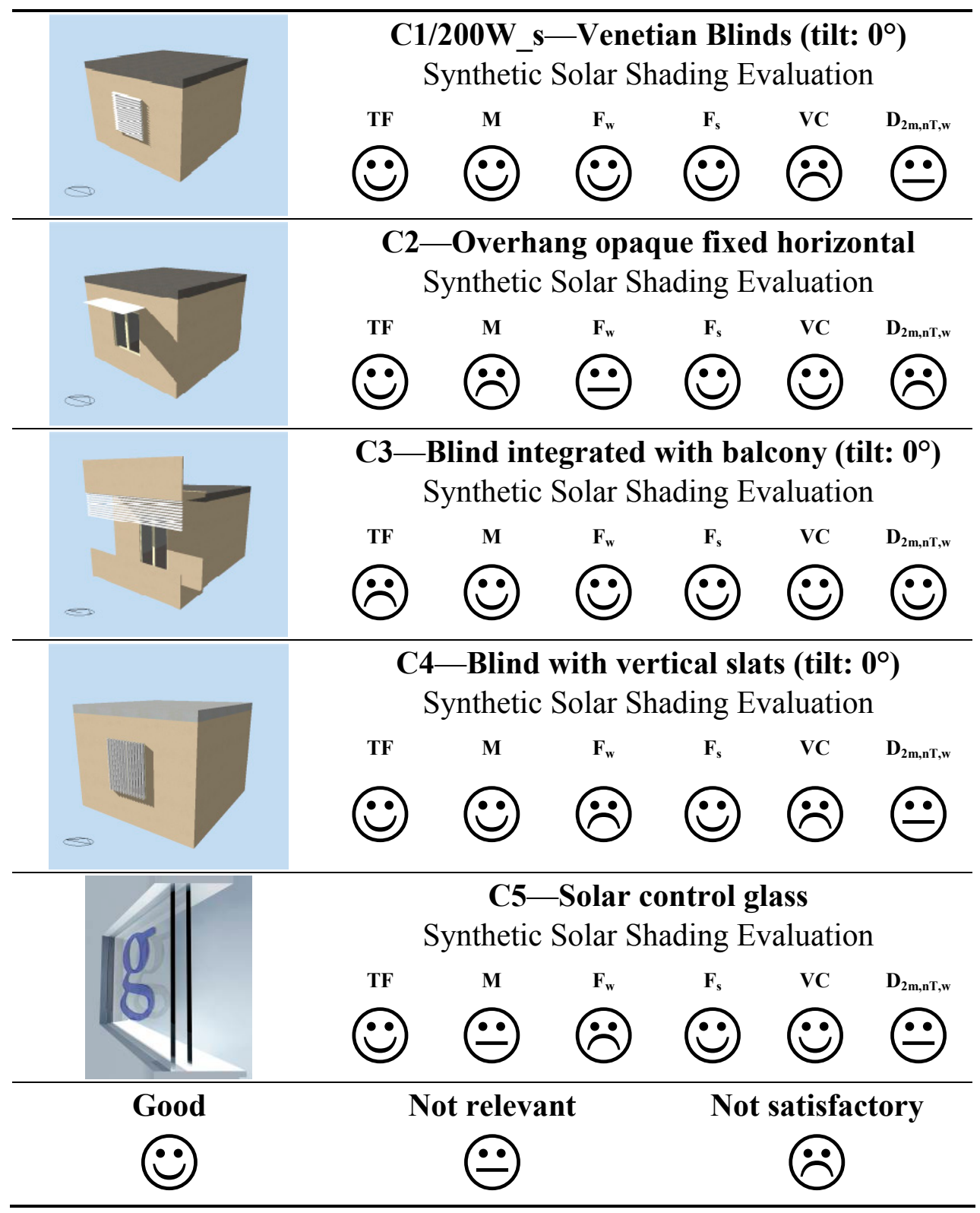

\section{Conclusions}

Starting from the preliminary results of a research carried out from 2008 to 2012, this paper presents a comparative analysis of the performance of different solar shading devices applied to the refurbishment of a typical post Second World War Italian building. For different orientations and climatic conditions (Berlin, Milan, Florence and Athens), the selected shadings have been classified and evaluated as for their thermal performances - solar gains in summer and winter-and thermal sensation of the occupants-operative temperature and hours outside the upper limit of the operative temperature.

The more effective shading systems reveal a high value of $F_{s}$ and a corresponding low value of $F_{w}$, then the higher the value $\Delta \mathrm{F}$ and the greater the shading effectiveness. For all the locations analyzed, for the south orientation, the insertion of a shading system (C3) on an existing balcony involves the best results, while the overhang opaque horizontal perpendicular to the facade $(\mathrm{C} 2)$ has good results but lower than $\mathrm{C} 3$ 
system. The venetian blind (C1) does not perform well when always closed during the year; to ensure more benefits is useful to combine these shading devices with a building automation system that manages the opening in a dynamic way, in relation to incident solar radiation. In the paper, the highly efficient behavior of the completely packed external venetian in winter season $(\mathrm{C} 1 / 200 \mathrm{~W}-\mathrm{s})$ is assessed.

The solar control glasses, having the same reduction of solar gains both in summer and in winter, can be considered a valuable alternative to the use of external shielding mostly in historical buildings and in historical areas.

Regarding the west orientation, in winter all the shading devices analyzed penalize the solar gains more than the same applied to south orientation; in particular, blinds with vertical slats $(\mathrm{C} 4)$ have a $\mathrm{F}_{\mathrm{w}}$ bigger than $\mathrm{F}_{\mathrm{s}}$.

Regarding thermal sensation, for all the locations, the solar shading devices and the solar control glass assessed highly affect the hours outside $\theta_{\mathrm{i} \text {,max }}$. Blinds integrated with balcony of $1.2 \mathrm{~m}$ depth (C.3) mostly reduce hours outside $\theta_{\mathrm{i} \text {,max }}$. The effect of the automatic control system of venetian blinds even if slightly increasing the hours outside $\theta_{i, \max }$ can guarantee a better visual comfort and daylighting. Moreover, the application of screening systems produces a reduction of the operative temperature ranging from about $1{ }^{\circ} \mathrm{C}$-with venetian blinds, horizontal overhang, sunscreen with vertical blinds and solar control glass - to more than $2{ }^{\circ} \mathrm{C}$ with integrated system on the balcony.

In general, the use of shading devices as passive control systems of the indoor conditions involves in summer time an improved thermal sensation as well as a reduction of thermal loads for air conditioning.

The control of seasonal solar gains cannot be the only criteria that guide the designer in choosing the shading strategy; in order to correctly choose a solar shading system, a global comparative analysis has been carried out based on a number of further fundamental aspects, such as: technical feasibility, management, visual comfort and acoustic performance.

The above mentioned holistic methodology has been applied to the case study located in Florence and the synthetic comparative evaluation has been reported in Data sheets. The future development of this research aims to apply this comparative evaluation to other cities, in order to achieve global guidelines for sustainable design.

\section{Acknowledgments}

The authors would like to acknowledge funding from Italian Research Program PRIN 2008 "Thermal, acoustic and lighting performances and shading devices of windows to improve energy efficiency of existing residential buildings".

\section{Author Contributions}

In this paper, Cristina Carletti contributed to research design and organized research flow; Leone Pierangioli developed case study simulations; Fabio Sciurpi contributed to data analysis and interpretation. All the authors contributed to writing of the article.

\section{Conflicts of Interest}

The authors declare no conflict of interest. 


\section{References}

1. Jelle, B.P.; Hynd, A.; Gustavsen, A.; Arasteh, D.; Goudey, H.; Hart, R. Fenestration of Today and Tomorrow: A State-of-the-Art Review and Future Research Opportunities. Sol. Energy Mater. Solar Cells 2012, 96, 1-28.

2. Asdrubali, F.; Baldinelli, G.; Bianchi, F. Influence of Cavities Geometric and Emissivity Properties on the Overall Thermal Performance of Aluminum Frames for Windows. Energy Build. 2013, 60, 298-309.

3. Beck, W.; Dolmans, D.; Dutoo, G.; Hall, A.; Seppänen, O. Solar Shading-How to Integrate Solar Shading in Sustainable Buildings, 1st ed.; REHVA: Brussels, Belgium, 2010.

4. Baldinelli, G.; Asdrubali, F.; Baldassarri, C.; Bianchi, F.; D’Alessandro, F.; Schiavoni, S.; Basilicata, C. Energy and Environmental Performance Optimization of a Wooden Window: A Holistic Approach. Energy Build. 2014, 79, 114-131.

5. Stevanović, S. Optimization of Passive Solar Design Strategies: A Review. Renew. Sustain. Energy Rev. 2013, 25, 177-196.

6. Atzeri, A.; Cappelletti, F.; Gasparella, A. Internal Versus External Shading Devices Performance in Office Buildings. Energy Procedia 2014, 45, 463-472.

7. CEN. Windows and Doors-Air Permeability-Classification; EN 12207; European Committee for Standardization: Brussels, Belgium, 1999.

8. CEN. Windows and Doors-Water Tightness-Classification; EN 12208; CEN: Brussels, Belgium, 1999.

9. CEN. Windows and Doors-Resistance to Wind Load-Classification; EN 12210; CEN: Brussels, Belgium, 1999.

10. CEN. Thermal Performance of Windows, Doors and Shutters. Calculation of Thermal Transmittance; EN ISO 10077-1; CEN: Brussels, Belgium, 2006.

11. Tsikaloudaki, K.; Theodosiou, T.; Laskos, K.; Bikas, D. Assessing Cooling Energy Performance of Windows for Residential Buildings in the Mediterranean Zone. Energy Convers. Manag. 2012, 64, 335-343.

12. Yao, J. Energy Optimization of Building Design for Different Housing Units in Apartment Buildings. Appl. Energy 2012, 94, 330-337.

13. Yao, J. A Multi-Objective (Energy, Economic and Environmental Performance) Life Cycle Analysis for Better Building Design. Sustainability 2014, 6, 602-614.

14. Cellai, G.; Carletti, C.; Sciurpi, F.; Secchi, S.; Nannipieri, E.; Pierangioli, L. Serramenti e Schermature per la Riqualificazione Energetica ed Ambientale. Criteri per la Valutazione e la Scelta, 1st ed.; EPC Editore: Roma, Italy, 2013.

15. Kim, G.; Lim, H.S.; Lim, T.S.; Schaefer, L.; Kim, J.T. Comparative Advantage of an Exterior Shading Device in Thermal Performance for Residential Buildings. Energy Build. 2012, 46, 105-111.

16. Lomanowski, B.A.; Wright, J.L. Modeling Fenestration with Shading Devices in Building Energy Simulation: A Practical Approach. In Building Simulation 2009, Proceedings of the 11th International IBPSA Conference, Glasgow, UK, 27-30 July 2009; pp. 976-983. 
17. Nikoofard, S.; Ismet Ugursal, V.; Beausoleil-Morrison, I. Technoeconomic Assessment of the Impact of Window Shading Retrofits on the Heating and Cooling Energy Consumption and GHG Emissions of the Canadian Housing Stock. Energy Build. 2014, 69, 354-366.

18. Lai, C.-M.; Wang, Y.-H. Energy-Saving Potential of Building Envelope Designs in Residential Houses in Taiwan. Energies 2011, 4, 2061-2076.

19. Cheung, C.K.; Fuller, R.J.; Luther, M.B. Energy-Efficient Envelope Design for High-Rise Apartments. Energy Build. 2005, 37, 37-48.

20. Florides, G.A.; Tassou, S.A.; Kalogirou, S.A.; Wrobel, L.C. Measures Used to Lower Building Energy Consumption and Their Cost Effectiveness. Appl. Energy 2002, 73, 299-328.

21. Palmero-Marrero, A.I.; Oliveira, A.C. Effect of Louver Shading Devices on Building Energy Requirements. Appl. Energy 2010, 87, 2040-2049.

22. Littlefair, P.; Ortiz, J.; Bhaumik, C.D. A Simulation of Solar Shading Control on UK Office Energy Use. Build. Res. Inf. 2010, 38, 638-646.

23. Tzempelikos, A.; Athienitis, A.K. The Impact of Shading Design and Control on Building Cooling and Lighting Demand. Sol. Energy 2007, 81, 369-382.

24. Nielsen, M.V.; Svendsen, S.; Jensen, L.B. Quantifying the Potential of Automated Dynamic Solar Shading in Office Buildings through Integrated Simulations of Energy and Daylight. Sol. Energy 2011, 85, 757-768.

25. Yao, J. Determining the Energy Performance of Manually Controlled Solar Shades: A Stochastic Model Based Co-Simulation Analysis. Appl. Energy 2014, 127, 64-80.

26. Yao, J. An Investigation into the Impact of Movable Solar Shades on Energy, Indoor Thermal and Visual Comfort Improvements. Build. Environ. 2014, 71, 24-32.

27. LBNL (US DOE). EnergyPlus Engineering Reference; LBNL: Berkeley, CA, USA, 2011.

28. CEN. Indoor Environmental Input Parameters for Design and Assessment of Energy Performance of Buildings Addressing Indoor Air Quality, Thermal Environment, Lighting and Acoustics; EN 15251; CEN: Brussels, Belgium, 2007.

29. CEN. Thermal Bridges in Building Construction-Linear Thermal Transmittance-Simplified Methods and Default Values; EN ISO 14683 CEN: Brussels, Belgium, 2007.

30. UNI. Acustica-Linee Guida per la Progettazione, la Selezione, l'installazione e il Collaudo dei Sistemi per la Mitigazione ai Ricettori del Rumore Originato da Infrastrutture di Trasporto (Acoustics-Guidelines for Design, Selection, Installation and Testing of Systems for Transportation Noise Reducing at Receivers); UNI 11296; UNI: Milano, Italy, 2009.

31. Baldini, S.; Carletti, C.; Cellai, G.; Nannipieri, E.; Sciurpi, F.; Secchi, S. Il controllo dell'irraggiamento solare: Effetti dei sistemi schermanti sotto il profilo acustico e illuminotecnico (Solar radiation control: Acoustic and lighting performance of shading devices). In Proceedings of the 48 AICARR International Conference, Baveno, Italy, 22-23 September 2011; pp. 195-206.

(C) 2014 by the authors; licensee MDPI, Basel, Switzerland. This article is an open access article distributed under the terms and conditions of the Creative Commons Attribution license (http://creativecommons.org/licenses/by/3.0/). 